\title{
The effects of physico-chemical characteristics of sandy soils amended with biochar, Ricinus and NPK (17-17-17) on the Okra (Abelmoschus esculentus) in Kinshasa (DR Congo)
}

Jeancy Ntuka Luta., Alasca Ekuya Lombolu., Paul Mafuka Mbe-Mpie.

University of Kinshasa, Faculty of Agricultural Sciences, Laboratory of Soil Science, BP 117 Kinshasa XI (DRC). Corresponding author : jeancyntuka@gmail.com

Original submitted in on $7^{\text {th }}$ September 2020. Published online at www.m.elewa.org/journals/ on $31^{\text {st }}$ December 2020 https://doi.org/10.35759/JABs.156.3

\begin{abstract}
Objectives: In order to improve the physico-chemical characteristics of sandy soils in Kinshasa, the biochar, leaves of Ricinus communis, NPK fertilizer and their combinations were used. Okra was grown as the test plant during two growing seasons.

Methodology and Results: The experimentation was carried in polyethylene bags with seven treatments and 4 replications. Each sand bag filled with sandy soil was amended with $300 \mathrm{gms} 900 \mathrm{gms}$ and $15 \mathrm{gms}$ respectively for biochar, Ricinus leaves and NPK which were only applied during the first cropping season. The soil was analysed before the trial and after each harvest. Biochar combined with mineral fertilizer and leaves of Ricinus leaves improved both Okra yield and the physico-chemical characteristics the soil. The highest yield in the first growing season was 6 times more than that of the control. In the second season, only the biochar associated with mineral fertilizer had given a satisfying yield.

Conclusion and application of results. For an integrated management of fertility of the sandy soil of Kinshasa, use of mineral fertilizers should be accompanied of rational application of organic matter. Biochar appears to be very useful to solve problems of water retention and nutrients brought to this type of soil. The price of fertilizer and biochar are not any time affordable by the smallholders; therefore the use of ricinus leaves, which are very accessible and easy to collect free of charge, appears to be economically profitable. By the way, yields obtained compared with these from fertilizer and biochar are the same.

Keywords: Sandy soil, biochar, pH, cation exchange capacity, organic matter, phosphorus.

\section{RESUME}

Objectifs : Dans la recherche de l'amélioration des caractéristiques physico-chimiques de sol sableux de Kinshasa, le biochar, les feuilles de Ricinus communis, le NPK et leurs combinaisons ont été utilisé.

Le Gombo a servi de plante texte pendant deux saisons culturales.

Méthodologie et résultats : L'expérimentation comprenait quatre répétitions et sept traitements. Les poquets amendés par $300 \mathrm{gr}$, $900 \mathrm{gr}$, et $15 \mathrm{gr}$ respectivement pour biochar, feuilles de ricin et NPK (17-17-17), étaient appliqués seulement à la 1 ère saison culturale. Le sol était analysé avant l'expérimentation et après chaque récolte. Le biochar combiné à l'engrais minéral et aux feuilles de ricin a amélioré à la fois le rendement de
\end{abstract}


gombo et les caractéristiques physico-chimiques étudiées du sol. Le rendement le plus élevé à la première saison était 6 fois plus que celui du témoin. A la deuxième saison, seul le biochar associé à l'engrais minéral a donné un rendement satisfaisant.

Conclusion et application des résultats : Pour une gestion intégrée de la fertilité de ce sol sableux de Kinshasa, l'utilisation des engrais minéraux devrait être accompagnée d'une application adéquate de la matière organique. Le biochar s'avère très important pour améliorer le problème de la rétention en eau et des éléments nutritifs à apporter à ce type de sol. Le prix des engrais et du biochar n'étant pas tout le temps abordable par les petits fermiers, l'utilisation des feuilles de ricin qui sont accessible et facile à ramasser sans frais s'avère économiquement rentable. En outre, le rendement obtenu, comparé à ceux de la combinaison des engrais et du biochar, il n'y a pas de différence.

Mots clés: Sols sableux, biochar, pH, capacité d'échange cationique, matière organique, phosphore.

\section{INTRODUCTION}

All soils of the world are not arable and those, which are arable, do not have the same potential production (Lahmar, 2009). Soils in the humid tropics are highly weathered, poor and are accompanied by shifting cultivation. Nowadays, a fallow of more than 15 years does not respond to the requirements in developing countries with a major increase in their population and in life expectancy (Nsombo et al., 2016). The main constraints that limit the potential of tropical soils are acidity, a low cation exchange capacity, low nutrient content and low organic matter content. Nowadays, soils are highly degraded due to severity of climate that seriously affects food security (Lahmar, 2009). In general, soils of Kinshasa are sandy soils. This sandy texture with $85 \%$ of sand gives to this soil a granular structure and an acid $\mathrm{pH}$ with an average of 5 . The low water retention capacity and nutrients for plants make them marginal soils for agricultural

\section{MATERIAL AND METHODS}

Soil sampling and organic fertilizers: The studied soil was sampled at the campus of University of Kinshasa. Geographical coordinates of the study area is $4^{\circ} 25^{\prime}$ South and $15^{\circ} 18^{\prime}$ East and $440 \mathrm{~m}$ of altitude. These soils were placed in polyethylene bags and mixed with biochar, Ricinus communis leaves, NPK and their combinations. The experimental set up used in this study was a completely randomized block made of seven treatments and four repetitions.

Soil analysis: Samples of each treatment were collected and air-dried in the lab before their analyses of the following parameters: $\mathrm{pH}, \mathrm{CEC}$, organic matter and available phosphorus. Soil pH was measured in a 1:2.5 ratio (weight/volume). CEC was determined by a paste production (ACF, 2009). They are submitted to a strong mineralization of organic matter and high weathering of nutrients due to intensive rainfall and high temperatures. To improve its fertility of sandy soils, farmers use organic matter of different types that make the main source of nutrients for crops (Muliele et al., 2017). Among organic fertilizers that are used, biochar is not part of this list and it is still unknown to these farmers. Yet, it has been recognized as an excellent fertilizer that contributes to increased water retention, nutrient retention and reduces soil acidity (Agegnehu et al., 2014; et al.; Glaser et al., 2014; El-Naggar et al., 2019; Yu et al., 2019). this study aims at assessing the impact of biochar and various fertilizers commonly used by farmers in Kinshasa on the physico-chemical characteristics of sandy soils in Kinshasa and their effects on Okra during two growing seasons.

extract with an ammonium acetate solution at $\mathrm{pH} 7$ and a soil-solution ratio of $1: 4$. Soil organic carbon was determined by the Walkley and Black method (Pauwels et al., 1992) that consists of oxidation of organic carbon by Potassium bichromate (K2Cr2O7) in a strong acid solution (H2SO4). The soil organic matter content was calculated by multiplying organic carbon content by a factor of 1,724 (the conversion factor is based on the fact that organic matter has on average $58 \%$ of organic carbon (Van Ranst et al., 1999). Phosphorus (in ppm) was determined using Atomic Absorption Spectrometer by the Olsen method in a 1:10 ratio (soil/ extraction solution of Olsen). 
Statistical analysis: Analysis of variance at 5\% significance level with the Statistix (2019) software has

\section{RESULTS AND DISCUSSION}

Physico-chemical properties of soil

Soil acidity: Figure 1 presents the results of soil the $\mathrm{pH}$ after two growing seasons after application of different been used in this study. Posthoc tests were performed to ass the differences between treatments.

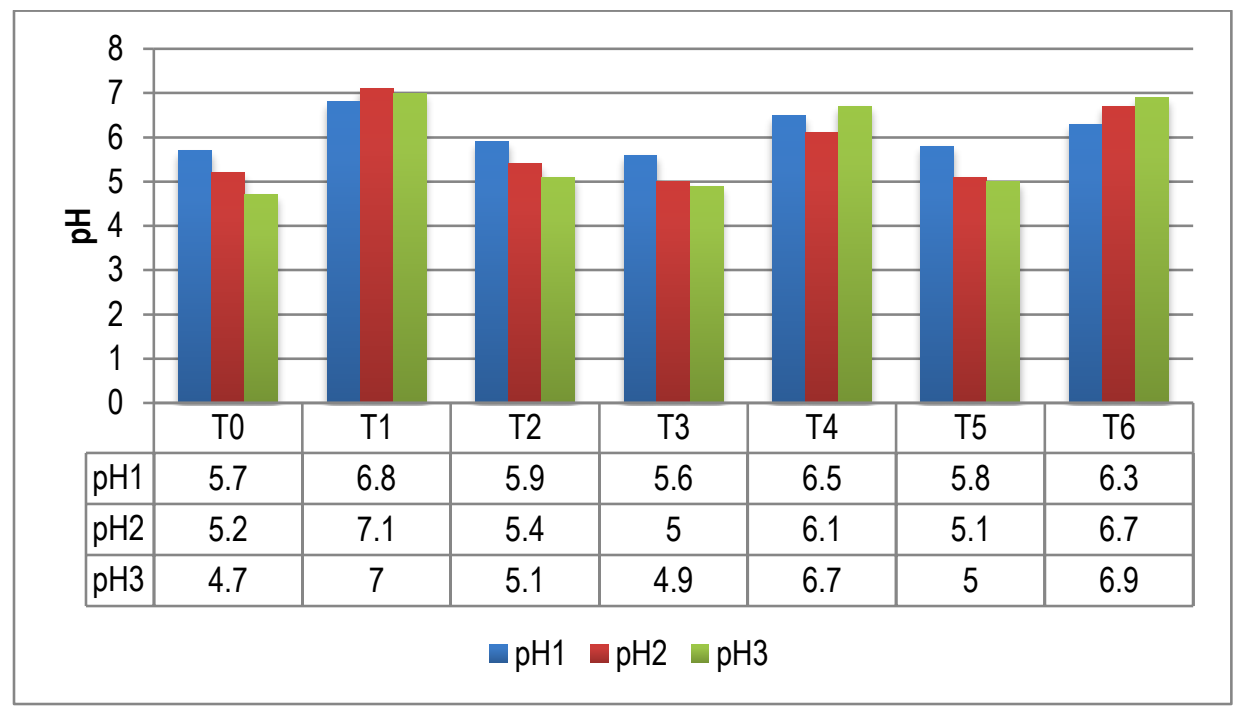

Figure 1: Results of soil pH

Legend:

$\mathrm{pH}$ : $\mathrm{pH} 1$ : after fertilizers application, $\mathrm{pH} 2$ : after the first growing season, $\mathrm{pH} 3$ : after the second growing season

Treatments (T)

T0 : Control ; T1 : Soil + biochar ; T2 : Soil + Ricinus leaves ; T3: Soil + NPK (17-17-17); T4: Soil + Biochar+ Ricinus leaves ; T5 :

Soil + NPK+ Ricinus leaves ; T6 : Soil+ Biochar+ NPK.

After the first growing season ( $\mathrm{pH} 1)$, only treatments with biochar i.e. T1, T4 and T6 yielded the same $\mathrm{pH}$ values. These results are similar to those found by Mustin (2013) who showed that biochar increased $\mathrm{pH}$ of acid soils of at least one unit. At the end of the second growing season, $\mathrm{pH}$ values decreased significantly in all the treatments except those with biochar. Decrease in $\mathrm{pH}$ in soils that were not treated with biochar were due to lixiviation of basic cations such as $\mathrm{Ca}^{2+}$ and $\mathrm{Mg}^{2+}$ and their substitution by $\mathrm{Al} 3+$ and $\mathrm{H}+$ in the soil complex as indicated by Lele (2016). Decrease in pH in soils where green manures were applied was also observed by Ruganzu (2009) and by Kaho et al. (2011). They showed that leaves of Tithonia diversifolia induced a decrease in treatments. This figure shows that after applying fertilizers before sowing, $\mathrm{pH}$ values were close to neutrality in all treatments and for the control. 


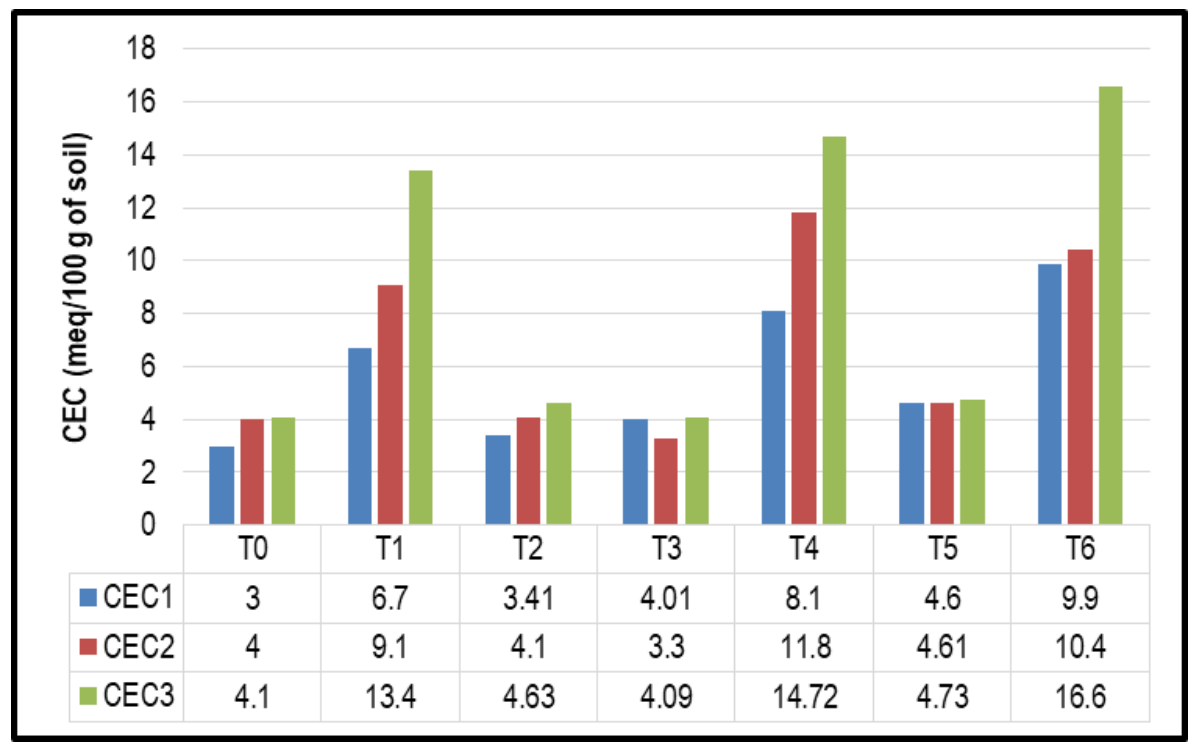

Figure 2: Values of Cation Exchange Capacity

Legend:

Cation Exchange Capacity (CEC)

CEC1 After fertilizers application, CEC2 After the first growing season, CEC3: After the second growing season

Treatments ( $T$ )

T0: Control; T1 : Soil + biochar ; T2 : Soil + Ricinus leaves; T3: Soil + NPK (17-17-17); T4: Soil + Biochar+ Ricinus leaves ; T5 :

Soil + NPK+ Ricinus leaves ; T6 : Soil+ Biochar+ NPK.

Figure 2 shows fertilizers have improved the CEC of the soil after their application. CEC of soils treated with biochars doubled and even tripled compared with control going from 3 to $6.7,8.1$ and 9.9. During the time of experimentation, the $\mathrm{CEC}$ values have kept increasing with treatments with biochar alone and combined (T1, T4 and T6). It has doubled from its initial value and was multiplied by 4 to 5 when compared to the control. On the other hand, other treatments did not induce any sensitive increase. Increase of CEC in the treatments with biochar is directly related to the carbon content and $\mathrm{pH}$ as indicated by Lele (2016). Similar results were obtained in tropical soils of Brazil with the application of biochar combined with compost (Shulz and Glaser, 2012) and with the application of biochar alone (Schulz et al., 2013). Low values of CEC obtained in soils amended with green manures and mineral fertilizers are in agreement with results obtained by previous authors that have worked in similar edapho-climatic conditions of Kinshasa (Koy, 2009; Mulaji, 2011 and Lele, 2016). The latter have obtained CEC values from 2.5 to $4.5 \mathrm{meq} / 100$ $\mathrm{g}$ soil. Increase in CEC in these soils treated with biochar was due to the fact it is a part of stable organic matters of the soil, favoring biological activity.

Organic matter: Figure 3 presents the evolution of soil organic matter during the two growing seasons. 


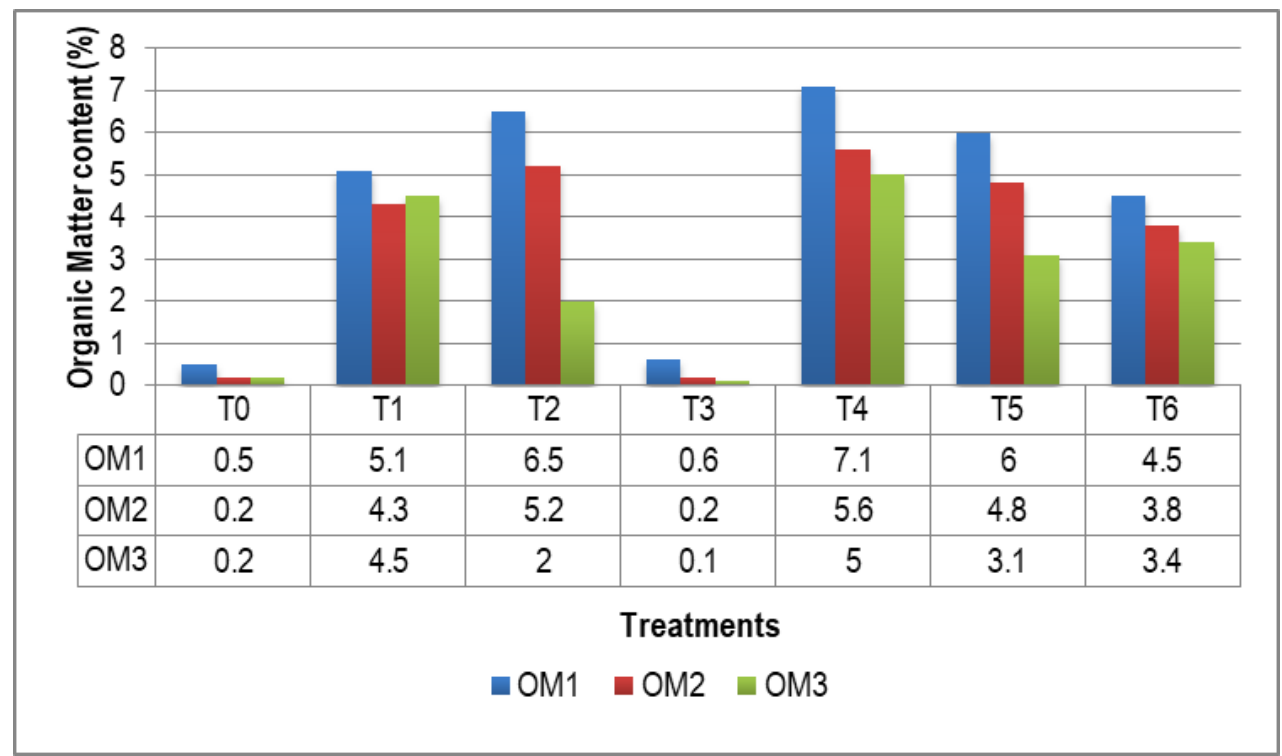

Figure 3: Organic matter values yielded by different treatments

Legend:

Organic matter (OM): OM1: After fertilizers application, OM2: After the first growing season, OM3: After the second growing season

Treatments (T)

T0: Control ; T1 : Soil + biochar ; T2 : Soil + Ricinus leaves; T3: Soil + NPK (17-17-17); T4: Soil + Biochar+ Ricinus leaves ; T5 :

Soil + NPK+ Ricinus leaves ; T6 : Soil+ Biochar+ NPK.

After application of fertilizers, soil organic matter (OM) content increased in all the soils treated with organic fertilizers with values 10 to 14 times greater to the control. After two growing seasons, these values were maintained with the treatments of $\mathrm{OM}$ but the values were found to be 17 to 25 times greater compared to the control where OM values decreased from 0.5 to $0.2 \%$. Results similar with control have been found by Koy (2009) in the Bateke Plateau and by Chaussod et al.
(1992) in ferralsol in Venezuela. Mulaji (2011) have found in soils of Kimwenza values ranging from 0.5 to 1\%. Moreover, Muliele et al. (2017) indicated that soils of Kinshasa are in general poor in OM. Its content varies around $1.83 \%$ and additional application of OM is often required.

Available phosphorus content $(P)$ in the soil: Figure 4 shows the evolution of available phosphorus during two growing seasons. 


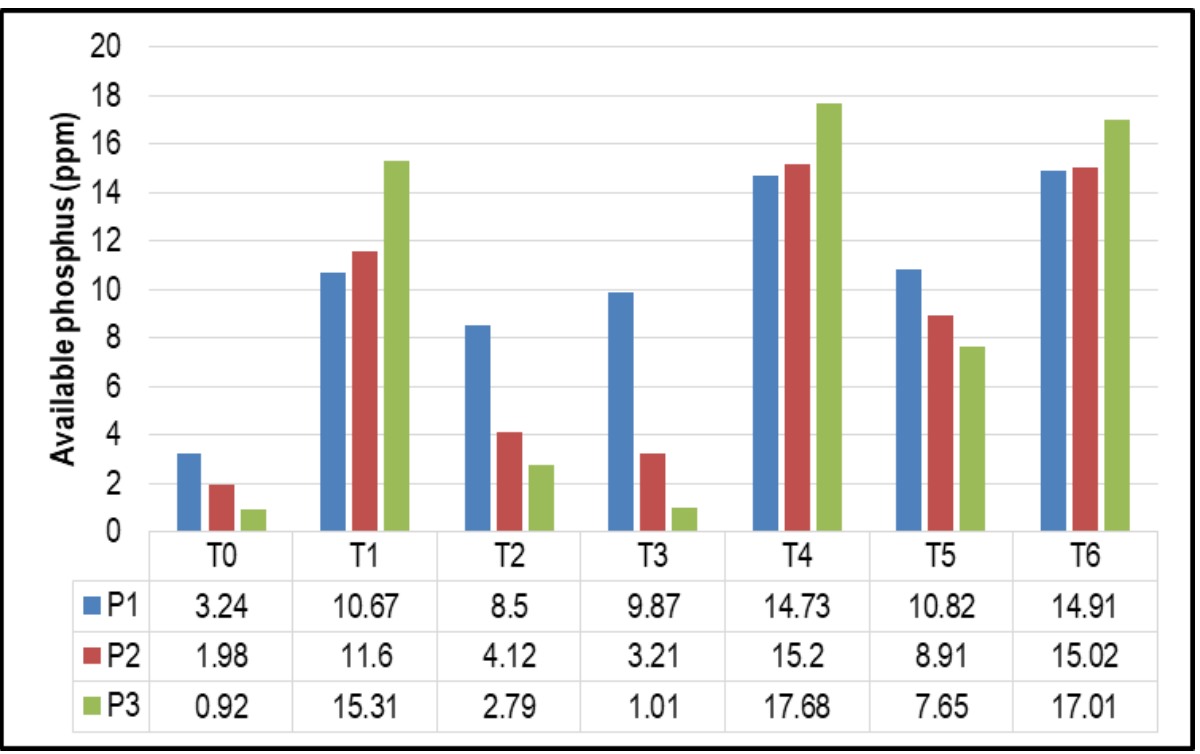

Figure 4: Available phosphorus content

Legend:

Phosphorus (P):P1: After fertilizers application. P2: After the first growing season, P3: After the second growing season Treatments ( $T$ )

Figure 4 shows that the fertilizers have increased the available soil phosphorus after fertilizer application. The content of available phosphorus has doubled compared to the control. During the experiment, the phosphorus content tended to decrease for all the treatments with the exception with biochars where it has increased. These treatments have induced a considerable increase in soil phosphorus. These results are similar to those of Lele (2016) revealing that the increase in phosphorus in treatments with biochar might be due to the combined effect of increase in $\mathrm{pH}$ above 6 and limited lixiviation. Mulaji (2011) indicated that the available phosphorus in the soil of Kinshasa varied around 7-13 ppm, whereas Koy (2009) presented values of available phosphorus in the region of Bateke Plateau with an average of $15 \mathrm{ppm}$. The threshold recommended by Landon (1991) for available phosphorus of tropical soils was greater than $15 \mathrm{ppm}$. Therefore, treatments with biochar can compensate the lack of available phosphorus in these soils. Great increase observed in the control (TO), in the treatment with Ricinus (T2), mineral fertilizer (T3), might be due to exportations, lixiviation and/or immobilization of ion phosphate due to decrease of $\mathrm{pH}$.

Table 1: Effects of different treatments on the production of Okra during two growing seasons.

\begin{tabular}{c|c|c}
\hline \multirow{2}{*}{ Treatments } & \multicolumn{2}{|c}{ Average weight of fruits (gr) } \\
\cline { 2 - 3 } & 1st season & $2^{\text {nd }}$ season \\
\hline$T_{0}$ & $27.6 \mathrm{e}$ & $0 \mathrm{f}$ \\
$\mathrm{T}_{1}$ & $38.6 \mathrm{e}$ & $9.8 \mathrm{e}$ \\
$\mathrm{T}_{2}$ & $177 \mathrm{ab}$ & $22.2 \mathrm{c}$ \\
$\mathrm{T}_{3}$ & $161.1 \mathrm{c}$ & $9.4 \mathrm{e}$ \\
& & \\
$\mathrm{T}_{4}$ & $165 \mathrm{bc}$ & $18.3 \mathrm{~d}$ \\
$\mathrm{~T}_{5}$ & $140 \mathrm{~d}$ & $27.5 \mathrm{~b}$ \\
$\mathrm{~T}_{6}$ & $179 \mathrm{a}$ & $49.2 \mathrm{a}$ \\
\hline Average & 127.0 & 19.5 \\
\hline LSD(5\%) & 12.8 & 3.0 \\
\hline
\end{tabular}

Legend: T0: Control; T1: Soil + biochar; T2 : Soil + Ricinus leaves; T3: Soil + NPK (17-17-17); T4: Soil + Biochar+ Ricinus leaves ; T5 : Soil + NPK+ Ricinus leaves ; T6 : Soil+ Biochar+ NPK. 
Effect of fertilizers on the production of Okra: Table 1 shows that use of organic and mineral amendments increase production more than 5 times during the first growing season compared to control. During the second growing season, no fruits were produced for the control. Production at the first growing season due to treatment with biochar combined with mineral fertilizers decreased of $73 \%$ despite the fact it was the best treatment. Increase in yield due to treatment with biochar combined

\section{CONCLUSION AND APPLICATION OF RESULTS}

This study has shown that combination of biochar with other amendments improve $\mathrm{pH}, \mathrm{CEC}, \mathrm{OM}$ and available phosphorus in sandy soils. The best yield in Okra during two growing seasons has been obtained with treatments through biochar with mineral fertilizer. Apart from decrease of soil acidity, biochar has improved the availability of phosphorus and of other nutrients that

\section{REFERENCES}

A.C.F. (Action contre la faim, ACF International) (2009). Rapport d'étude sur l'agriculture périurbaine (maraîchage) de Kinshasa. Province de Kinshasa, RD Congo.

Agegnehu, G., Srivastava, A.K., Bird, M.I., 2017. The role of biochar and biochar-compost in improving soil quality and crop performance: a review. Applied Soil Ecology 119: 156-170.

Chaussod, R., Zuvia, M., Breuil, M.C., Hetier, J.M. (1992). Biomasse microbienne et « statut organique » des sols tropicaux : exemple d'un sol vénézuélien de Llonos sous différents systèmes de culture. Cah. Orstom., sér. Pédol., vol. XXVII, $n^{\circ} 1: 59-67$.

El-Naggar, A., Lee, S.S., Rinklebe, J., Farooq, M., Song, H., Sarmah, A.K., Ok, Y.S., (2019). Biochar application to low fertility soils: a review of current status, and future prospects. Geoderma 337: $536-554$

Glaser, B., Wiedner, K., Seelig, S., Schmidt, H.-P., Gerber, H., (2015). Biochar organic fertilizers from natural resources as substitute for mineral fertilizers. Agronomy for Sustainable Development 35: 667-678.

Kaho F., Yemefack M., Feujio-Teguefonet et Tchantchaouang J.C., (2011). Effet combiné des feuilles de Tithonia diversifolia et des engrais inorganiques sur les rendements du maïs et les propriétés d'un sol ferralitiques au Centre Cameroun. Tropicultura. 29 (1) : 39-45. by mineral fertilizer might be due to the influence of biochar in the improvement of physico-chemical characteristics of the soil as reported in Figures 1,2 and 4. Moreover, these results show that use of biochar improve soil productivity in the long term. In general, decrease in yield has been observed in all the treatments during the second growing season. The most important decrease were observed in the treatments without biochar

were not analysed in this study.Biochar can really improve the fertility of the soil if it is combined with other sources of nutrients. This study shows that for a good productivity of sandy soils in Kinshasa, it is recommended to use $300 \mathrm{~g}$ of biochar per seed hole for orchards' vegetable.

Koy, K.R. (2009). Amélioration de la qualité des sols sableux du plateau de Batéké (R D Congo) par application des matériels géologiques et des déchets organiques industriels locaux. Thèse de doctorat, Sciences de la Terre, Université de Gand, Gent, p 323.

Lahmar R (2009). Le sol épiderme vivant de la terre. Agropolis international, numéro 8. P5

Landon J.R., 1991. Booker Tropical Soil Manual. A handbook for soil survey and agricultural land evaluation in the tropics and subtropics. United states, New York, $474 \mathrm{p}$.

Lele N.B, Kachaka S.C, Lejoly L (2016). Effet du biochar et des feuilles de Tithonia diversifolia combinéà l'engrais minéral sur la culture dumaïs (Zea mays $L$.) et les propriétés d'un sol ferralitique à Kinshasa (RDC)

LELE N.B., (2016). Potentiel d'amélioration de la fertilité des sols sableux et acides de Kinshasa (RDC) par l'usage du charbon de bois (biochar), de la biomasse végétale et des engrais minéraux. Thèse (Université de Liège).

Monkiedje A., Spiteller M., Fotio D. et Sukul P., (2006). The effect of land use on soil health indicators in peri-urban agriculture in the humid forest zone of southern Cameroon. Journal Environnement Qaul., 35 : 2402-2409.

Mulaji K, C., (2011). Utilisation des composts de biodechets menagers pour l'amélioration de la fertilité des sols acides de la province de 
Kinshasa (République Démocratique du Congo) p.86-94

Muliele M, T., Nsombo M, B., Kapalay M, O., Mafuka M$M, P$ (2017). Amendements organiques et dynamique de l'azote minéral dans le sol sableux de Kinshasa (RD Congo). Journal of Animal \&Plant Sciences, 2017. Vol.32, Issue 2 : 5156-5167

Musti M, (2013). Le biochar : Rôle agronomique et environnemental.

(RITTMO

Agroenvironnement Recherche Innovation Transfert de Technologie pour les Matières fertilisantes Organiques). p.9

Nsombo M. B., Lumbuenamo S. R., Aloni K.J.2 , Lejoly J., Mafuka M-M.P (2016). Effet des plantations d'Acacia sp sur les macronutriments primaires des sols sableux d'lbi village au plateau des Bateke (Kinshasa, République Démocratique du Congo). Revue Scientifique et Technique Forêt et Environnement du Bassin du Congo. Volume 6.P.1

Ntuka L, J (2018). Impact des biochars d'Acacia sp et d'Hymenocardia acida sur la rétention en eau du sol et la production de l'aubergine (Solanum melongena). Mémoire de fin d'étude, Fac agro/ Unikin.

Pauwels J., E. Van Ranst, M. Verloo et A. Mvondo (1992). Manuel d'Analyses de sols et de plantes. Equipements, Gestion de stocks, de verrerie et produits chimiques. Publications agricoles-28, AGCD, Bruxelles, Belgique. 265 p.

Ruganzu V., (2009). Potentiel d'amélioration de la fertilité des sols acides par l'apport de biomasses végétales naturelles fraîches combinées à du travertin au Rwanda. Thèse de doctorat. Université de Liège-Gembloux AgroBio Tech/Belgique. 215p.

Schulz H. and Glaser B., (2012). Effects of biochar compared to organic and inorganic fertilizers on soil quality and plant growth in a greenhouse experiment. Journal of Plant Nutrition and Soil Science. 175(3) : 410-422.

Schulz H., Dunst G. et Glaser B., (2013). Positive effects of composted biochar on plant growth and soil fertility. Agronomy for Sustainable Development. 33(4) : 817-827

Van Ranst E., M. Verloo, A. Demeyer, and J.M. Pauwels (1995). Manual for Soils and Fertility Laboratory. Analytical Methods for Soils and Plants. Equipment and Management of
Consumables. Faculty of Bioscience engineering. University of Ghent, Belgium. 243 p.

Yu, H., Zou, W., Chen, J., Chen, H., Yu, Z., Huang, J., Tang, H.,Wei, X., Gao, B., (2019). Biochar amendment improves crop production in problem soils: a review. Journal of Environmental Management 232: 8-21. 